\title{
Kajian Linguistik Fungsional Sistemik: Analisis Hubungan Sistem Transitivitas dan Konteks Situasi dalam Pidato Presiden Jokowi Soal Penanganan Virus Corona
}

\author{
Muhamad Faisal Assyuza'), Miftahulkhairah Anwar ${ }^{2)}$ \\ Pascasarjana UNJ \\ email: MuhamadFaisalAssyuza_9905820008@mhs.unj.ac.id ${ }^{1)}$ \\ email: miftahulkhairah@unj.ac.id ${ }^{2)}$
}

\begin{abstract}
The study aims to describe the Systemic Functional Linguistics (SFL) study regarding the relationship between the transitivity process system and circumstant of the situation in President Jokowi's speech about the handling of the COVID-19. This research is a descriptive study with a qualitative approach. The source that used to be the object of this study was the text of President Jokowi's speech on the handling of the COVID-19. Data collection did not involve the author directly, but data was obtained from the Kabar24 website which was uploaded on March 15, 2020. The data collection technique used in this study was the reading comprehension technique which was carried out with a concentration on the object to be studied. The results showed that the total number of processes was 57 data. The number of material process occurrences was 31 data with an emergence percentage of 54\%, then followed by the Mental process with 11 data occurrences, with an appearance percentage of $19 \%$, the Relational process the number of occurrences was 6 data with an appearance percentage of $11 \%$, the Behavioural process the number of occurrences was 3 data with an occurrence percentage of 5\%, the Verbal process was 2 data with an appearance percentage of $4 \%$, and finally the Existential process was 4 data with an appearance percentage of $7 \%$. The number of circumstance recorded in time 1 and place 10.

Keywords: Transitivity, Circumstance, Text of President Jokowi's Speech on the Handling of the Corona Virus
\end{abstract}

\section{Pendahuluan}

Teks didefinisikan suatu bahasa yang digunakan sebagai ungkapan suatu kegiatan sosial baik secara lisan maupun tulis dengan struktur berpikir yang lengkap (Mahsun, 2014: 1). Dari penjelasan tersebut dapat kita ketahui bahwa teks adalah suatu ungkapan yang dikeluarkan dengan tujuan mengungkapkan kegiatan sosial atau berorientasi pada tujuan sosial, bentuk teks tidak hanya berupa tulisan dengan struktur yang lengkap, melainkan juga bisa berupa lisan. Teks berorientasi pada tujuan sosial yang dimaksud adalah bahwa dalam teks tersebut terdapat sesuatu hal yang ingin dicapai (Hutmiyati dkk: 2017).

Sama halnya dengan pendapat sebelumnya, Zainurrahman mengatakan teks merupakan seperangkat unit bahasa baik lisan maupun tulisan dengan ukuran tertentu, makna tertentu, 
Kajian Linguistik Fungsional Sistemik: Analisis Hubungan Sistem Transitivitas dan Konteks Situasi dalam Pidato Presiden Jokowi Soal Penanganan Virus Corona (Muhamad Faisal Assyuza, Miftahulkhairah Anwar)

serta tujuan tertentu (Zainurrahman dalam Ida Yeni Rahmawati, 2014: 50). Pendapat di atas mengatakan bahwa teks merupakan seperangkat unit bahasa lisan dan tulisan dengan karakteristik tertentu; memiliki ukuran tertentu, makna tertentu, dan tujuan tertentu.

Ricoeur dalam Rahmawati Ida Yeni (2014: 50) mengajukan suatu definisi yang mengatakan bahwa teks adalah wacana (berarti lisan) yang diklasifikasikan ke dalam bentuk tulisan. Berbeda dengan penjelasan sebelumnya penjelasan Ida ini mengatakan bahwa teks merupakan wacana lisan yang diklasifikasikan ke dalam bentuk tulisan. Dengan demikian semua jenis teks adalah wacana lisan yang dituliskan. Dari pendapat di atas dapat disimpulkan teks merupakan salah satu komponen dalam bahasa lisan maupun tulis yang diklasifikasikan menggunakan media tulis dengan tata organisasi tertentu yang berorientasi pada tujuan sosial yaitu terdapat hal yang ingin dicapai.

Dapat diketahui bersama, dalam Bahasa terdapat beberapa jenis teks teks beberapa teks yang secara garis besar terbagi ke dalam dua jenis teks yaitu teks sastra dan non sastra. Adapun kedua jenis teks tersebut tentu memiliki ciri, karakteristik dan tujuan yang berbeda-beda. Teks sastra adalah sebuah teks yang bercirikan menyampaikan suatu pesan melalui bahasa keindahan atau menggunakan pilihan diksi yang indah. Sedangkan teks nonsastra merupakan teks yang berisi penyampaian pesan dengan menggunakan bahasa yang lugas dan baku atau disesuaikan dengan kaidah kebahasaan yang ada.

Lebih lanjut Nurfaedah (2017) mengungkapkan keberadaan bahasa sebagai teks selalu dikelilingi oleh lingkungannya, baik fisik maupun nonfisik yang secara langsung mendukung keberadaan suatu teks atau dengan kata lain teks selalu berada di dalam konteksnya. Penjelasan di atas menjelaskan bahwa mengungkapkan keberadaan bahasa sebagai teks selalu dikelilingi oleh lingkungannya yang artinya penggunaan suatu teks tidak selalu sama tergantung pada situasi dan kondisi yang ada, dan tujuan dari penyampaian informasi yang diinginkan. Dengan memilih jenis teks yang tepat segala informasi dapat tersampaikan dengan baik tidak akan ada kesalahan persepsi yang tidak tepat oleh penerima atau pembaca.

Pada penjelasan sebelumnya telah dikatan bahwa teks tidak hanya teks tertulis saja namum ada juga teks yang ungkapkan dalam bentuk lisan, salah satu jenis teks yang diungkapkan dalam bentuk lisan adalah teks pidato. Teks pidato adalah penyajian lisan di depan sekelompok masa dan berhasil menguasai masa serta dapat menyampaikan gagasan yang dapat diterima orang lain (Budiyanti, 2015: 18-19). Ahli ini mengungkapkan bahwa teks pidato adalah sebuah teks berisi penyampaian sebuah gagasan yang disajikan atau diungkapkan secara 
lisan di depan sekelompok masa yang telah berhasil dikuasai oleh pembicara tersebut sehingga gagasan yang ingin disampaikan dapat tersampaikan dan dapat diterima oleh pendengar.

Teks pidato adalah teks atau naskah yang digunakan oleh seorang yang berpidato untuk menyampaikan ide kepada orang banyak (Pasek Widiantara I Wayan: 2014). Penjelasan ini menjelaskan bahwa teks pidato merupakan teks yang bertujuan untuk menyampaikan ide kapada khalayak. Seorang yang mengungkapkan pidato berarti ia ingin menyampaikan ide atau gagasannya kepada semua orang yang menjadi pendengarnya.

Dari ahli-ahli di atas dapat disimpulkan bahwa pidato adalah sebuah penyajian teks secara lisan yang dilakukan di depan umum yang bertujuan untuk menyampaikan gagasan yang dapat diterima kepada khalayak, agar gagasan dapat dengan mudah diterima oleh khalayak maka dalam penyusunan teks pidato harus menggunakan kata-kata yang mudah dipahami dan disampaikan secara runtut.

Nugroho (2018) mengungkapkan dalam menuliskan teks pidato seseorang harus mahir dalam mengolah kata dan kalimat sehingga nantinya jika dilisankan akan terdengan runtun dan baik. Penjelasan di atas mengatakan bahwa penulis teks pidato harus mahir dalam mengolah kata. Yang termasuk ke dalam pengolahan kata antara lain pemilihan diksi yang tepat, pemilihan bahasa yang digunakan harus disesuaikan dengan psikologi dan latar belakang pendengar, dan penempatan tanda baca yang sesuai. Sehingga dapat diungkapkan dalam bahasa lisan dengan baik, mudah untuk dipahami oleh pendengar dan tidak menyinggung psikologi pendengar.

Telah diketahui bersama bawah setiap teks memiliki unsur pembentuk teks dan struktur masing masing, Budiyanti (2016) mengungkapkan unsur yang ada pada teks pidato antara lain: (1) Pembukaan: salam, sapaan, ungkapan puji syukur. (2) Isi pidato berisi tentang uraian inti/pokok dari suatu pidato. Pada bagian ini paparan dari pembicara menduduki persentase yang paling banyak. Pembicara akan menguraikan secara rinci dari materi yang akan disampaikan kepada khalayak. (3) Penutup meliputi simpulan, harapan, dan penutup. Pembukaan adalah unsur yang paling awal diungkapkan yang berisi salam, sapaan, ungkapan puji syukur dan juga salawat kepada Nabi Muhammad SAW, pada tahap ini pembicara belum mengungkapkan gagasan yang akan disampaikannya pada tahap ini pembicara berusaha mengalihkan pandangan pendengar kepada dirinya agar ketika mengungkapkan gagasan pendengar terfokus dan siap menerima gagasan yang disampaikan. Setelah pembukaan diugkapkan barulah masuk ke dalam tahap isi, pada tahap ini pembicara mengungkapkan gagasan inti yang ingin disampaikan dan pada tahap ini menduduki persentase paling banyak 
Kajian Linguistik Fungsional Sistemik: Analisis Hubungan Sistem Transitivitas dan Konteks Situasi dalam Pidato Presiden Jokowi Soal Penanganan Virus Corona (Muhamad Faisal Assyuza, Miftahulkhairah Anwar)

karena disamping menyampaikan gagasan inti pembicara berusaha untuk meyakinkan pendengar agar mau mendengar gagasan yang disampaikannya. Tahap terakhir merupakan tahap penutup, tahap ini berisi simpulan dari isi gagasan yang disampaikan, harapan yang ingin dicapai, permohonan maaf dan ditutup dengan salam.

Lebih lanjut lagi Budiyanti (2016) juga menungkapkan hal yang perlu disiapkan oleh orang yang berpidato antara lain (1) menentukan topik dan tujuan pidato. Selanjutnya, (2) menganalisis pendengar dan situasi engan menganalisis situasi akan didapatkan jalan keluar untuk menyiapkan cara cara bagaimana pembicara harus menyesuaikan diri dalam menyampaikan uraiannya dan memberi jalan untuk menentukan suatu sikap yang harus diambil dalam menghadapi para pendengar. Penjelasan di atas menjelaskan hal-hal yang harus dipersiapkan ketika ingin berpidato. Yang pertama adalah menentukan topik atau yang ingin dibacarakan. Topik atau gagasan yang dibicarakan bisa timbul dari tujuan atau kepentingan pembicara dalam menyampaikan pidato tersebut, selain itu topik bisa muncul dari kebutuhan pendengar. Hal yang perlu diperhatikan berikutnya adalah lingkungan tempat berpidato. pembicara harus mengetahui lingkungan berpidato agar mengetahui latar belakang pendengar baik latar belakang sosial, ekonomi dan bahasanya agar tidak terjadi hal-hal yang dapat menyinggung perasaan pendengar, dengan begitu pembicara dapat mempersiapkan cara penyampaian berpidato baik dari segi penggunaan bahasa, sikap atau tata krama.

Pada penjelasan awal sudah dijelaskan bahwa teks pidato adalah teks yang berorientasi pada tujuan sosial, artinya terdapat proses komunikasi dari pembicara kepada pendengar untuk menyampaikan informasi tertentu. Dengan demikian teks pidato adalah pemakaian bahasa yang erat kaitannya dengan fungsional, dalam istilah linguistik istialah ini di kenal dengan istilah linguistik fungsional sistemik yaitu melihat bahasa dari sisi fungsi bahasa itu sendiri. Oleh sebab itu penulis sangat tertarik untuk membuat sebuah kajian dari sebuah teks pidato dengan menggunakan pendekatan linguistik fungsional sistemik.

\section{Landasan Teori}

Penulis mencoba menerapkan pendekatan linguistik fungsional sistemik (LFS) untuk mengkaji pidato Presiden Jokowi soal penanganan virus corona. Penulis ingin mengetahui kata kerja apa yang lebih banyak muncul jika ditinjau jenis-jenis proses yang ada pada kepresidenan, sirkumstan serta kaitannya dengan konteks situasi.

Dalam LFS dikenal istilah transivitas, transivitas mulai didiskusikan pada perkembangan keempat dalam teori LFS. Menurut Halliday (dalam Teguh, 2019), sistem 
transivitas menjelaskan pengalaman linguistik pengguna bahasa yang diatur oleh jenis proses. Dalam pembahasan LFS, bagian pengalaman yang sempurna dihubungkan dalam klausa yang dibagi menjadi tiga unsur, yakni proses, parsitipan, dan sirkumstan.

\section{Gambar 1}

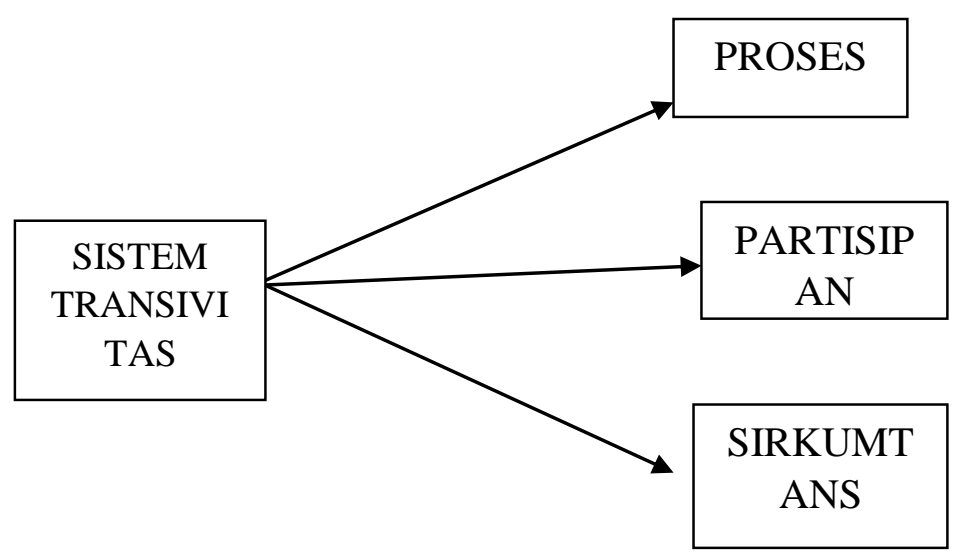

Jika ditarik ke dalam nuansa linguistik, transitivitas bisa dilihat dari berbagai sudut pandang. Ketransitifan suatu klausa dapat diukur jika dilihat dari sudut semantik dan gramatikalnya. Dalam kaitan ini kata kerja yang berperan dalam suatu klausa atau kalimat bisa berupa kata kerja transitif ataupun intransitif. Berbeda dengan istilah transitivitas yang dibahas dalam tulisan ini. Secara umum, transitivitas dapat dikatakan menjelaskan bagaimana suatu makna direpresentasikan dalam suatu kalimat.

Terdapat tipe-tipe transitivitas antara lain proses material, proses mental, proses relasional, proses behavioral atau tingkah laku, proses verbal, dan terakhir proses eksistensial atau proses wujud. Di bawah ini akan dijelaskan proses-proses transivitas menurut Saragih, A (dalam Zul Haeri, 2016):

1. Proses material adalah aktivitas fisik atau kegiatan yang menyangkut fisik dan nyata dilakukan pelakunya. Kerena sifatnya yang demikian proses material dapat diamati dengan indera. Dalam proses material, pelaku setara dengan subjek, proses material setara dengan predikat, gol setara dengan objek dan sirkumstan setara dengan keterangan.

2. Proses mental menunjukkan kegiatan atau aktivitas yang menyangkut indera, kognisi, emosi, dan resepsi yang terjadi di dalam diri manusia. Seperti melihat, mengetahui, menyenangi, membenci, menyadari, dan mendengar. Dalam proses mental, pengindera 
Kajian Linguistik Fungsional Sistemik: Analisis Hubungan Sistem Transitivitas dan Konteks Situasi dalam Pidato Presiden Jokowi Soal Penanganan Virus Corona (Muhamad Faisal Assyuza, Miftahulkhairah Anwar)

setara dengan subjek, mental setara dengan predikat, fenomena setara dengan objek dan sirkumstan setara dengan keterangan.

3. Proses relasional menghubungkan satu entitas dengan maujud atau lingkungan lain di dalam hubungan intensif, sirkumstan, atau kepemilikan dan dengan cara (mode) identifikasi satu atribut. Secara sistemik, jenis proses relasional tersebut dapat diringkas sebagai berikut. (a) Proses: relasional: Intensif: identifikasi (b) Proses: relasional: intensif: atribut, (c) Proses: relasional: sirkumstan: identifikasi, (d) Proses: relasional: sirkumstan: atribut, (e) Proses: relaional: kepemilikan: identifikasi, (f) Proses: relasional: sirkumstan: atribut

4. Proses tingkah laku merupakan aktivitas atau kegiatan psiologis yang menyatakan tingkah laku fisik manusia. Yang termasuk proses tingkah laku adalah verba bernafas, pingsan, berbatuk, sendawa, menguap, tidur, tersenyum, mengeluh, tertawa, menggerutu. Dalam proses tingkah laku, petingkah laku setara dengan subjek, proses tingkah laku setara dengan predikat dan sirkumstan setara dengan keterangan.

5. Proses verbal. Menurut Saragih, proses verbal berada antara proses mental dan relasional. Dengan demikian, proses verbal sebagian memiliki ciri proses mental dan sebagian lagi memiliki ciri relasional. Dalam proses relasiona, penyampai pembicara setara dengan subjek, proses verbal setara dengan predikat, penerima perkataan setara dengan objek, dan sirkumstan setara dengan keterangan.

6. Proses wujud menunjukkan keberadaan atau entitas. Secara semantik, proses wujud terjadi antara proses material dan proses relasional. Dalam proses wujud, proses wujud setara dengan predikat, maujud setara dengan objek, dan sirkumstan setara dengan keterangan.

Dari penjelasan di atas dapat kita ketahui bahwa terdapat enam tipe transivitas atau terdapat enam proses. Pertama yaitu proses material yaitu aktivitas yang melibatkan fisik pelakunya dan terlihat nyata. Kedua adalah proses mental, yaitu proses yang menyangkut indera, kognisi, emosi, dan resepsi yang terjadi di dalam diri manusia seperti melihat, merasa, mencium, mendengar, menyayangi, membenci, marah dan lain sebagainya. Ketiga proses rasional yaitu proses yang menghubungkan satu entitas dengan lingkungan lain, pada penjelasan di atas disebutkan pula jenis proses rasional secara sistemik. Keempat proses behavioral atau proses tingkah laku, yaitu aktivitas atau kegiatan psikologis yang menyatakan tingkah laku fisik manusia seperti bernapas, tertawa, menangis, tersenyum mengeluh, tertidur dan lain sebagainya. Kelima proses verba yaitu penyampai pembicara setara dengan subjek, 
proses verbal setara dengan predikat, penerima perkataan setara dengan objek, dan sirkumstan setara dengan keterangan. Keenam proses ekstensial atau proses wujud, yaitu proses yang terjadi antara proses material dan rasional.

Saragih (dalam Teguh, 2019) berpendapat bahwa sirkumstan adalah lokasi tempat berlangsungnya proses. Konsep sirkumstan setara dengan keterangan dalam tata bahasa baku tradisional. Zul Haeri (2016) Sirkumstan merupakan lingkungan, sifat, atau lokasi berlangsungnya proses. Sirkumstan berada di luar jangkauan proses. Sirkumstan terdiri atas rentang yang dapat berupa jarak atau waktu, lokasi yang dapat mencakupi tempat atau waktu, cara , sebab, lingkungan, penyerta, peran, maslah dan sudut pandang. Telah dijelaskan pada dua penjelasan ahli di atas bahwa sirkumstan tidak berada pada jangkauan proses sirskumstan terdiri atas waktu dan tempat.

Berikut ini adalah sirkumstan dalam bentuk bagan:

\section{Gambar 2}

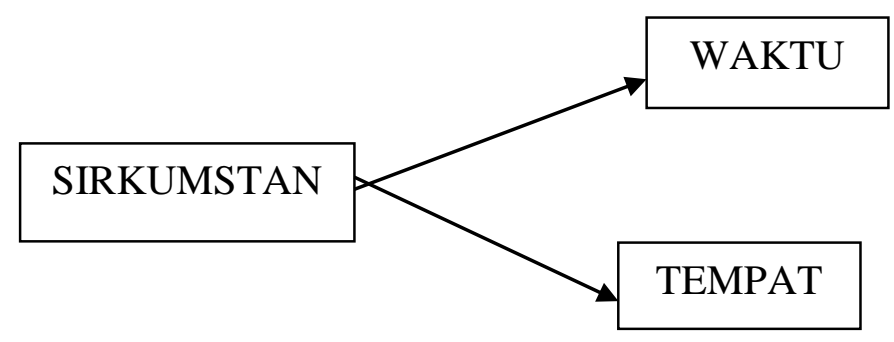

\section{Metode Penelitian}

\subsection{Jenis Penelitian}

Metode yang digunakan dalam penelitian ini yaitu studi deskriptif yaitu penelitian kebahasaan yang menggunakan Tata Bahasa Sistemik Fungsional sebagai acuan. Jenis penelitian deskriptif kualitatif yang dipakai dalam peneltian ini dimaksudkan untuk menganalisis sistem transitivitas dan konteks situasi pada Pidato Presiden Jokowi Soal Penanganan Virus Corona.

\subsection{Polpulasi dan Sampel}

Populasi dalam penelitian ini adalah keseluruhan teks yang terdapat dalam pidato Presiden Jokowi Soal Penanganan Virus Corona. Pemilihan sampel dalam penelitian ini dilakukan dengan cara pupisive sampling yaitu penentuan sampel dengan pertimbangan tertentu (Arikunto, 2010). Sampel penelitian ini adalah hasil dari analisis yaitu proses, partisipan dan sirkumstan yang diwujudkan dalam sistem transitivitas. 
Kajian Linguistik Fungsional Sistemik: Analisis Hubungan Sistem Transitivitas dan Konteks Situasi dalam Pidato Presiden Jokowi Soal Penanganan Virus Corona (Muhamad Faisal Assyuza, Miftahulkhairah Anwar)

\subsection{Sumber Data}

Sumber data yang digunakan sebagai data dalam tulisan ini adalah sumber tulisan dari pidato Presiden Jokowi soal penanganan virus corona. Pemerolehan data tidak melibatkan penulis secara langsung tetapi data diperoleh dari websait Kabar24 yang di unggah pada 15 maret 2020 .

\subsection{Teknik Pengumpulan Data}

Teknik pengumpulan data yang digunakan dalam penelitian ini adalah teknik membaca pemahaman yang dilakukan dengan konsentrasi pada objek yang akan diteliti. Teknik ini digunakan karena sumber data berupa data tulisan atau teks. Kemudian memilah teks pidato tersebut dalam bentuk bentuk paragraf, dari paragraf dipilah ke dalam bentuk klausa, dari klausa-klausa tersebut akan diperoleh sistem transitivitas data yang dianalisis yang terdiri dari kategori proses, partisipan, dan sirkumstan.

\section{Hasil dan Pembahasan}

Dalam pidato Presiden Jokowi soal penanganan virus corona, ditemukan tipe-tipe transitivitas antara proses material, proses mental, proses relasional, proses behavioral, proses verbal, dan terakhir proses eksistensial.

Tabel 1

\begin{tabular}{|l|c|c|}
\hline \multicolumn{1}{|c|}{ Tipe Transitivitas } & Jumlah Kemunculan & Presentase Kemunculan \\
\hline Proses material & 31 & $54 \%$ \\
\hline Proses mental & 11 & $19 \%$ \\
\hline Proses relasional & 6 & $11 \%$ \\
\hline Proses behavioral & 3 & $5 \%$ \\
\hline Proses verbal & 2 & $7 \%$ \\
\hline Proses eksistensial & 4 & $100 \%$ \\
\hline Jumlah & 57 & \\
\hline
\end{tabular}

Dari tabel 1 diketahui persentase kemunculan proses berbeda-beda. Proses yang mendominasi adalah proses Material yang jumlah kemunculannya dalam data sebanyak 31 data dengan persentase kemunculan 54\%, kemudian disusul dengan proses Mental yang jumlah 
kemunculannya dalam data sebanyak 11 data dengan persentase kemunculan 19\%, proses Relasional jumlah kemunculannya dalam data sebanyak 6 data dengan persentase kemunculan $11 . \%$, proses Behavioral jumlah kemunculannya dalam data sebanyak 3 data dengan persentase kemunculan 5\%, proses Verbal jumlah kemunculannya dalam data sebanyak 2 data dengan persentase kemunculan 4\%, dan terakhir proses Eksistensial jumlah kemunculannya dalam data sebanyak 4 data dengan persentase kemunculan $7 \%$.

Kemudian dalam pidato Presiden Jokowi soal penanganan virus corona, ditemukan sirkumstan sebagai berikut:

\section{Tabel 2}

\begin{tabular}{|l|c|c|}
\hline \multicolumn{1}{|c|}{ Sirkumstan } & Jumlah Kemunculan & Persentase \\
\hline Waktu & 1 & $9 \%$ \\
\hline Tempat & 10 & $91 \%$ \\
\hline Jumlah & 11 & $100 \%$ \\
\hline
\end{tabular}

Dari tabel 2 diketahui persentase kemunculan sirkumstan berbeda-beda. Sirkumstan waktu jumlah kemunculannhya hanya 1 data dengan persentase kemunculan 9\%, kemudian sirkumstan tempat jumlah kemunculannya dalam data sebanyak 10 data dengan persentase kemunculan $91 \%$.

\section{Simpulan dan Saran}

\subsection{Simpulan}

Berdasarkan deskripsi hasil penelitian dan pembahasan, dapat disimpulkan bahwa tipe proses yang ditemukan dalam analisis pidato Presiden Jokowi soal penanganan virus corona terdiri dari 6 Proses yakni Proses Material, Proses Mental, Proses Relasional, Proses Behavoiral, Proses Verbal, dan Proses Eksistensial. Kemunculan proses material sebagai peringkat tertinggi bermakna bahwa dalam pidato yang disampaikan oleh Presiden Jokowi, ia ingin menekankan bahwa harus lebih banyak melakukan aksi nyata, untuk mencegah penyebaran virus corona dan menstabilkan perekonomian Indonesia.

\subsection{Saran}

Saran dalam penelitian ini adalah harus menambah kebiasaan membaca untuk menambah wawasan dan penguasaan terhadap konsep materi, dan tingkatkan kemampuan dalam mengkaji teks secara menyeluruh. Untuk itu peneliti memberikan saran kepada peneliti 
Kajian Linguistik Fungsional Sistemik: Analisis Hubungan Sistem Transitivitas dan Konteks Situasi dalam Pidato Presiden Jokowi Soal Penanganan Virus Corona (Muhamad Faisal Assyuza, Miftahulkhairah Anwar)

lain yang ingin meneliti lebih lanjut penelitian terkait kajian fungsional sistemik ini untuk meneliti lebih mendalam lagi agar dapat meningkatkan kemampuan orang-orang yang berada dalam lingkup linguistik terutama yang membahas tentang analisis linguistik fungsional teori transitivitas.

\section{Daftar Pustaka}

Arikunto, Suharsimi. (2010). Media Pembelajaran. Surakarta: Yuma Pustaka.

Budiyanti. 2015 "Peningkatan Keterampilan Berpidato Melalui Teknik ATM (Amati Tiru Modifikasi) Berbasis Kartu Acak Pada Peserta Didik Kelas IXd SMP Negeri 2 Banyubiru Semester 2 Tahun Pelajaran 2014/2015" Kompas" dalam JPK 2 (1) (2016): 17-25 19.

Budiyanti 2016. "Peningkatan Keterampilan Berpidato Melalui Teknik ATM (Amati Tiru Modifikasi) Berbasis Kartu Acak Pada Peserta Didik Kelas IXd SMPNegeri 2 Banyubiru Semester 2 Tahun Pelajaran 2014/2015” dalam JPK 2 (1) (2016): 17-25 2016.

Hutmiyati, Miftahulkhairah Anwar, dan Aulia Rahmawati. 2017. "Struktur Teks Prosedural Pada Majalah Genie” dalam Arkhais, Vol. 08 No. 2 Juli -Desember 2017.

Mahsun. 2014. Teks dalam Pembelajaran Bahasa Indonesia. Jakarta. PT. Rajagrafindo Persada.

Nugroho Agung .2018 “Analisis Teks Pidato Mahasiswa Program Studi Bahasa Dan Sastra Indonesia Stkip-Pgri Lubuklinggau” dalam Jurnal Perspektif Pendidikan Vol 12 No 1 Juni 2018.

Nurfaedah. 2017. “Analisis Hubungan Sistem Transitivitas dan Konteks Situasi dalam Pidato Politik Hatta Rajasa: Tinjauan Sistemik Fungsional" dalam Jurnal Retorika, Volume 10, Nomor 1, Februari 2017, hlm. 1-71.

Pasek Widiantara I Wayan. 2014. "Kajian Retorika dalam Naskah Pidato pada Siswa Kelas X.1 SMA Negeri 1 Pupuan" dalam e-Jurnal Pendidikan Bahasa dan Sastra Indonesia, Undiksha Volume: Vol: 2 No: 1 Tahun:2014.

Rahmawati, Ida Yeni. 2016. "Analisis Teks dan Konteks pada Kolom Opini "Latihan Bersama Al Komando 2014” Kompas" dalam Jurnal Dimensi Pendidikan dann Pembelajaran Vol. 5. Januari 2016. hlm. 49-57.

Teguh, Maulana Perdana 2019 “Kajian Linguistik Fungsional Sistemik(Lfs) Dalam Teks Rjmd Kabupaten Tegal Tahun 2014 - 2019”

Zul Haeri 2016. "Kajian Linguistik Fungsional Sistemik Pada Terjemahan Al-Quran Surah AlInsan Dan Relevansinya Terhadap Pembelajaran Wacana Di Perguruan Tinggi" Volume IX Nomor 1 Januari - Juni 2016. 